\title{
DOES "FREE"1 HIGHER EDUCATION IN SOUTH AFRICA MAKE ECONOMIC SENSE? VIEWS OF COMMERCE STUDENTS
}

\author{
E. De Jager* \\ e-mail: edejager@sun.ac.za
}

\author{
R. Baard* \\ e-mail: rbaard@sun.ac.za \\ *School of Accountancy \\ Stellenbosch University \\ Stellenbosch, South Africa
}

\section{ABSTRACT}

Student protests demanding "free" higher education at South Africa universities in 2015 is a reminder that there are still a lot of unresolved issues regarding the inequalities due to the apartheid era in the higher education system. Some of these issues include insufficient state funding of higher education, the increase of tuition fee and unpaid student debt. Even though "free" higher education sounds appealing, the question is whether implementing "free" higher education would make economic sense in South Africa.

The study aimed to investigate the perceptions of commerce students at one South African university regarding the economic feasibility of "free" higher education and how it might affect the South African economy. The research aimed to give a descriptive analysis of the perceptions of commerce students and were empirically investigated by means of a questionnaire, containing both open and closed questions. Gaining understanding into student perceptions can be invaluable, as they are considered the livelihood of higher education institutions.

The results show that the respondents do not think that "free" higher education make economic sense in South Africa as the economy is too weak and there is too much corruption and wasteful spending in government. The respondents also indicated that the economy will mostly be negatively affected by "free" higher education in that there will be an increase of the financial burden on the South African economy and tax payer. They also regard other government services to be of greater importance than implementing "free" higher education.

The results of this study are not necessarily generalisable beyond the scope of the particular institution, but the findings do create a platform for the continued debate on the importance, economic feasibility and implementation of "free" higher education in South Africa.

Keywords: free higher education, student protests, South Africa's economy, economic sense, \#FeesMustFall 


\section{INTRODUCTION}

Higher education holds the prospect of mediating social equity, economic and social growth, and democratic citizenship. However, due to many reasons, such promises of mediation are often not realised, especially in South Africa (Badat 2016). The country's legacy of inexcusable inequalities due to apartheid had a damaging effect on higher education, resulting in uneven access, different success rates for different students as determined by factors such as race, gender, class, region as well as unequal employment opportunities, and unequal staffing resources (Waghid 2002; Shrivastava and Shrivastava 2014). Many of these issues, together with the main goal of insisting "free" higher education for all, are the reasoning behind recent protests in South Africa.

South Africa encountered large-scale protests in 2015 by university students who demanded "free" higher education (Cloete 2016a). The \#FeesMustFall protests started at the end of 2015, shortly after the announcement of increased university fees in South Africa. These protests originated at 14 universities within South Africa and are deemed one of the most effective campaigns, which attracted considerable media attention (Venter 2016). The protests have been very successful in engaging the country in a timely discussion regarding higher education and government policies, seeing that many public policies in South Africa have been without public discussion or debate as of late (Pienaar 2016). Yet, despite the fact that the students were being heard, their voices might have been resonating too loud, as protests like these could create an image of disorder and chaos (Venter 2016). Although the student protests in 2015 were seen as one of the most effective campaigns, the phenomenon was not unfamiliar to South Africa. Various protests have occurred in the post-apartheid era since 1994 (Davids 2016). Be that as it may, the recent protests were a glaring reminder that many students cannot afford university fees (Hull 2015) and one of the most profound posters in the 2015 protests read: "Our parents were SOLD dreams in 1994. We are just here for the REFUND" (Badat 2016).

South Africa does have a shortage of skills that hamper the economy (Van der Merwe 2016). Thus, the question can be asked whether "free" higher education would not make economic sense to help the country with these shortfalls. Firstly, the World Bank has found that holding a degree leads to a better chance of employment. Secondly, it was uncovered that South Africa has a high private return on tertiary higher education (Cloete 2016b). Thirdly, education is one of the main aspects of a country, as it enables students to find their potential, enhance their capability and, as a result, contribute to the country's development (Pienaar 2016). Therefore, the common sense notion is that education would produce a more productive economy, which, in turn, will result in economic growth, yielding benefits for the whole country 
(Maistry 2014). Regardless of the fact that South Africa already invests billions of Rands in higher education, and that these investments are crucial to the intellectual and economic growth of the country (Memela 2015), at least one analyst, Co-Pierre George, is of the opinion that South Africa cannot afford not to have "free" higher education (Van der Merwe 2016).

As much as the proposition of "free" higher education is appealing, education is never actually "free" (Teferra 2016). Someone must pay for it. South Africa's higher education minister admitted that even though "free" higher education would be ideal, it does not seem to be economically feasible (Hull 2015). This view is supported by the recently released report of the Fees commission, set up by former South African president, Mr Zuma, shortly after the \#FeesMustFall protests started. The report, which stated that universal "free" tertiary education will not be attainable in the foreseeable future, took into account the struggling economy of South Africa and the competing demands on the budget (Cele and Nhlabathi 2017). "Free" higher education would be too costly to implement, given the fact that government resources are not infinite (Wangenge-Ouma and Cloete 2008). Thus, the leadership of South African was at the time concerned about the financial and wider economic costs associated with the demands of the protests (Pienaar 2016). Some authors argued that, in the long run, South Africa rather needs an equitable funding model and a just payment system (Hull 2015) to ensure affordable higher education for everyone. Cloete (2016a) agrees, suggesting that students should call for affordable, rather than "free" higher education.

The major purpose of the present study was to assess the views of commerce students concerning the economic feasibility of "free" higher education in South Africa and to determine whether to them it makes economic sense. The study was conducted at one South African university with a rich historical background of apartheid, which will be discussed in the methodology section. Students in the field of commerce were selected as respondents as they might have a better insight into the kinds of issues, which concern the South African economy compared to students in other study fields.

\section{LITERATURE REVIEW}

In 1994 South Africa had their first multicultural elections after which the government faced challenges to set out educational notions that would help dismantle the legacies of apartheid and establish a higher education structure that would focus on transformation. Transformation issues included equal entrance, development, accountability and quality (Waghid 2002). The current White Paper (the primary policy document in the Post-School Education and Training (PSET) system) includes a number of education priorities; however, it does not make provision for "free" higher education (Pienaar 2016). 
Consequently, students were starting to demand an education system, which includes "free" higher education for all. It became clear that "free" higher education has both advantages and disadvantages (Wangenge-Ouma and Cloete 2008; Hull 2015; Maistry 2014; Cloete 2016a). A review of relevant literature highlighted this position and explained the possible footprint of "free" higher education on the economy of South Africa as we discuss next.

\section{Advantages and disadvantages}

A major advantage of "free" higher education would be to gain access to higher education for many students, increasing the social demand for higher education (Wangenge-Ouma and Cloete 2008). There is evidence that there is a statistically significant beneficial pay-off between human capital and the growth of a country's rate of per capita income (Gyimah-Brempong, Paddison and Mitiku 2006) and as the gradual gathering of human capital is a major vehicle of growth, "free" higher education would seem to make economic sense to a country in the long run. Economic growth also relies on basic skills, literacy, numeracy, and computer science and technology that are covered in an education system (Maistry 2014). A faster education growth rate might thus result in faster transition growth rates and higher incomes. Hence, investment in higher education can be seen as a favourable investment, especially in developing countries (Shrivastava and Shrivastava 2014).

Furthermore, more graduates would be ideal in a country suchlike South Africa, as holding a degree is both a personal and a public good (Hull 2015). Higher education access to the poor may lead to positive outcomes, especially in South Africa where there are high-income disproportions, costly crime rates and skills shortages (Wangenge-Ouma and Cloete 2008). Private benefits would include greater employment possibilities, desirable salaries, better health and enhanced quality of life (Shrivastava and Shrivastava 2014).

Moreover, Van der Merwe (2016) asserts that, given the current lack in leadership in government, a strengthened higher education system, which develops strong future leaders, is imperative. In addition, Waghid (2002) maintains that transforming higher education would be good for a shift in the mentality of the people of South Africa, from being racist, undemocratic and authoritarian to becoming a nation with fewer inequalities.

Yet, even though the outcome of "free" higher education might be valuable for the country, the actual protests of 2015 and later reflected badly on South Africa and had a negative economic impact. Investors were concerned, resulting in the weakening of the Rand/Dollar exchange rate (Venter 2016).

Furthermore, Maistry (2014) argues that, although economic growth is regarded as beneficial for any country, it does not automatically lead to a better life for all, especially in a 
less-developed country. It is believed that "free" higher education might even widen inequality instead of reducing it (Cloete 2016a). A well-known South African economist, Servaas van der Berg, states that funding higher education in a non-OECD (Organisation for Economic Cooperation and Development) country such as South Africa would benefit the higher income groups, because most current students come from these families. In the same vein, Johan Fourie argues that, as the wealthy are presumably the ones to access higher education, funding "free" higher education might mean a contribution for the rich or alternatively seen as a tax on the poor (Cloete 2016a). Wangenge-Ouma and Cloete (2008) concur that the rich may receive the advantage from "free" higher education, seeing that children from higher socio-economic backgrounds normally attend better schools in terms of quality and, in turn, dominate in higher education profiles.

The financial resources for "free" higher education would need to come from somewhere. This could mean decreased government spending on other services; money borrowed, or increased taxes. Various analysts like Dr Bheki Mngomezulu, Daniel Silke and Dawie Roodt are of the view that South Africa is not performing well and cannot meet the expense of "free" higher education at this stage (Weekend Argus 2017). They therefore believe that it would be reckless in an already suffering economy to make higher education and training "free" and that it could potentially damage the country (Weekend Argus 2017). If the state is not able to provide the funding, the tax burden will increase which might further harm the economy and might result in a very angry nation (Weekend Argus 2017). Increased taxes entail the contribution of the whole nation, while in a country such as South Africa there is no rationale for the poor to sponsor the rich (Teferra 2016). The predominant objection to "free" higher education is therefore not that it is unfeasible; instead, it would be viewed as inequitable. Full public allocation is not always the way to social fairness (Hull 2015) and might not be possible in South Africa if the right public choices are not made (Badat 2016).

In the early 1990s Wolpe (1991) argued that the resources (including economic resources) that would be needed to rectify all aspects of education under the apartheid system will only be available in the very long run, if at all.

\section{Percentage of GDP and the budget}

South Africa generates its revenue mostly through tax and borrowing money from world-wide financial institutions, which is then allocated to public institutions according to the country's national plan and priorities (Teferra 2016). The role of government regarding education policy and education funding is critical to any country, as education is seen as one of the vital cornerstones of economic, social and political development (Shrivastava and Shrivastava 
2014).

Every year, South Africa has to allocate its budget to a variety of urgent and competing public needs, which include education, public health, public infrastructure and public safety (Teferra 2016). Hull (2015) refers to the strong arguments often made for free high school education or free health care. The question remains: Which service is the most important? Over the past few years, primary health care budgets have increased steadily (UNICEF 2016). In 2018, government stated that expenditure on health care is a key priority (Chowles 2018). There have also been many arguments to support primary education at the cost of higher education, as the private and social returns would be more beneficial to the country (Gyimah-Brempong et al. 2006). Bloom, Canning and Chan (2006) also point out that the belief exists that basic education (including primary and secondary education) are more critical than higher education, as they are often seen as the drivers of social welfare (Shrivastava and Shrivastava 2014). Nevertheless, some argue that in developing countries higher education is essential for an improved economy (Shrivastava and Shrisvastava 2014). Education is considered an instrument to promote economic growth and is essential to reduce poverty (Bloom et al. 2014) however; every percentage point that is spent on higher education is one that cannot be spent on other needs (Teferra 2016).

It remains a concern that higher education is highly underfunded in South Africa and that far less funds is spent on this division than in many other developing countries (Badat 2016). Treasury argues that there is no money available for the funding of higher education, but some may argue that the national budget needs reprioritisation (Van der Merwe 2016). According to former South African president, Jacob Zuma, "You can't have a flourishing budget when the economy is in trouble" (Wild and Mbatha 2015).

One way of measuring the state's commitment to higher education is to look at the percentage of the Gross Domestic Product (GDP) that is allocated and distributed to that specific sector (Badat 2016). GDP is a monetary measure of the market value of all final goods and services produced in a period for a specific country (Brooks 2012). South Africa has spent between 0.68 per cent and 0.72 per cent of its total budget on higher education between 2004 and 2016 (Badat 2016), which is a much smaller percentage than what other African countries spend on average towards higher education (Vally et al. 2016).

The GDP percentage that other counties spend on higher education varies as follows (Vally et al. 2016; Van der Merwe 2016; Badat 2016):

- $\quad$ United Kingdom: 1\%

- $\quad$ Botswana: $1 \%$ 
- $\quad$ Ghana and Senegal: $1.4 \%$

- Malaysia: $1.75 \%$

- $\quad$ Norway and Finland: $>2 \%$

- China: $3 \%$

- $\quad$ Cuba: $4.5 \%$

The South African budget for higher education for the 2015/16 year amounted to around R30 billion. Even if the government were to spend 1 per cent of the GDP on higher education, which would amount to R41 billion (Cloete 2015), the money received from the South African government would only represent around 30 per cent of the income of public universities (Vally et al. 2016). Due to a continuous decline in economic growth, government is forced to reduce subsidies to public universities (Waghid 2002). Thus, in recent years, funding from the government for higher education (as a percentage of GDP as well as a percentage of total government finance) has declined (Wangenge-Ouma and Cloete 2008).

Every sector is competing for a portion of the budget, but a shift can only happen if there is honest and open engagement regarding the issue of the utilisation of resources, including information on wasteful projects and malfeasance (Vally et al. 2016). Unfortunately, instead of focusing on what is important for the country, the current South African government appears to be wasting money on political infighting and corruption (Van der Merwe 2016).

\section{Funding money}

If higher education becomes "free" in South Africa, then a substantial increase in funding is required (Pienaar 2016). The question remains, however: Where will the money come from?

Many belief that "free" higher education would be possible in South Africa if the proportion of GDP to higher education increases and if the rich are taxed more (Cloete 2016a). However, even if the proportion of the state budget increased from 0.75 per cent to 1 per cent, which is a good target to realise immediately, it would not be sufficient to satisfy the demand (Badat 2016).

In a study performed to establish the financing implication of implementing the policies of the White Paper, excluding "free" higher education yet, it was found that if the policies were to be implemented in 2030, between R352 billion and R654 billion would be needed annually in the Postsecondary Education and Training system. Thus, even without "free" higher education, between 2 per cent and 5 per cent of the current GDP (in real terms) would be needed annually by 2030 (Pienaar 2016). Moreover, the Davis Tax Committee (DTC) maintains that if 
"free" higher education was only provided to all students that meet the requirements to go to university in the form of comprehensive grants, 1.5 per cent of the GDP must be awarded, which seems unrealistic (Cronje 2017).

In the study by Pienaar it was estimated that the cost to implement "free" tuition fees in higher education over the next three years (2017/18 - 2019/20) would be around R90.5 billion (Pienaar 2016). In another study it was found that, an additional R19.7 billion would be required annually to appropriately fund the higher education system (Badat 2016), while the Davis Tax Committee (DTC) estimated that an additional R60 billion would be needed annually (Cronje 2017). The exact amount of money needed for "free" higher education is thus quite difficult to estimate, but what seems certain is that it will be a significant amount, which could accrue to tens of billions of rands (Badat 2016).

Hence, additional sources of funding would be needed to implement "free" higher education. Such sources could include an increase in taxes, reducing wasteful and ill-conceived government expenditure and government loans. Still, even if revenue streams could be freed up, the amount of money that is required will be substantial and hard to argue that "free" higher education is possible. It would further mean that higher education would have to compete with all other government-spending priorities (Pienaar 2016).

Relevant literature points to the advantages and disadvantages that "free" higher education would have. It also highlights the monetary effect it would have on South Africa's economy. Against this background, students from the Faculty of Economic and Management Sciences (EMS) at a South African university were invited to air their views on whether "free" higher education would make economic sense in South Africa. The reasoning behind choosing this group of students for the study was based on the assumption that they would probably be more informed to offer views on the economy of South Africa than students from other fields of study.

\section{METHODOLOGY}

\section{Background}

An exploratory interpretive study, using a survey questionnaire, was employed to investigate student perceptions regarding the economic viability of "free" higher education in South Africa. The university at which the study was conducted has a historical background established in the apartheid agenda. This university was formally established in 1918 and was associated in intricate ways to the earlier apartheid government. Before the 1990s, the university mainly provided for white Afrikaans-speaking students. However, since changing its policies for 
admission considerably during the 1990s, a wider range of students has been admitted. The current language policy also promotes multilingualism. The change in admission policies has increased the percentage of generic black students to 40 per cent of the total population of students in 2016. The university consists out of 10 faculties, with the EMS faculty being one of the biggest faculties in terms of student numbers.

It is assumed that students of the EMS faculty are well informed about the economics and finances of a country. The reason being that all the academic programmes in the EMS faculty incorporate financial, economic, and managerial disciplines and thus these students study issues pertaining to these disciplines. It was therefore argued that these EMS students might be better informed to make inferences on whether "free" higher education makes economic sense compared to students in other faculties. This does not imply that non-commerce students in other faculties cannot make similar conclusions but judged to have been a good starting point. The study generated the views of EMS faculty students during 2016. This is the same year during which the \#FeesMustFall campaign continued after it had started in the previous year.

Obtaining insights into student views and perceptions can be valuable as students are often considered as "customers", and is therefore the essence of higher education institutions (Bunce 2017). If the views and perceptions of students are better understood, it might add to the general satisfaction in a higher education institution (Nell and Cant 2014). Furthermore, the information can be used by certain groups such as the Department of Higher Education and Training to make decisions about higher education issues.

\section{Research aim}

The aim of the study was to investigate the opinions of EMS students regarding whether they consider "free" higher education as making economic sense in South Africa. In addition, the inquiry wanted to determine whether students think the South African government is able to provide "free" higher education and how it might affect the economy, either positively or negatively. The study further asked commerce students on how much it would cost to implement "free" higher education and whether they think, higher education is more important than other government services. Hence, the main research question: Do EMS students think "free" higher education makes economic sense in South Africa?

\section{Student survey}

The research aimed at providing a descriptive analysis of the views of EMS students at a South African university (Henning, Van Rensburg and Smit 2004) using a validated survey questionnaire. The questionnaire contained both open and closed questions and was e-mailed 
to 6004 EMS students at the particular South African university. The respondents were given two weeks to complete the online questionnaire. The respondents could complete the questionnaire voluntarily and anonymously. The research design and methodology aimed to make the study replicable and prior to distributing the questionnaire, the necessary ethical clearance and institutional permission for the study were sought.

The questionnaire contained three parts. The first part of the questionnaire consisted of questions relating to the background variables of the students. The second part consisted of closed questions, where students were asked to respond to statements using a five-point Likert scale, varying from 1 to 5 (where 1 = "completely disagree" and 5 = "completely agree"). In the second part of the questionnaire, students were also asked to rate general statements regarding the economic feasibility of "free" higher education. The last section of the questionnaire consisted of a number of open-ended questions, asking students' opinions on the economic feasibility of "free" higher education. Questions such as the following were included: Does "free" higher education makes economic sense? Is the South African government able to provide "free" higher education, and how would it affect the economy if implemented? Students were also asked to air their views on whether other government services are more important than higher education and what it would cost to implement "free" higher education.

\section{Biographical information of student respondents}

The majority of students registered in the EMS commerce faculty in 2016 were invited to participate. The students from three departments of the EMS faculty were excluded from the study because they are not situated on the main campus of the university. All undergraduate and postgraduate courses in the EMS faculty contain a financial and economic basis and a total of 6004 of these students were included in the survey via e-mail. A response rate of 20 per cent (1 201 respondents) was achieved. A minimum sample size of 10 per cent of the total target population is recommended for a descriptive study (Gay 1987). The results obtained can therefore be generalised to the target population for students enrolled at the EMS faculty of the particular South African university, but not beyond this parameter.

The study involved 51.4 per cent female and 48.6 per cent male students and the respondents comprised 84.7 per cent undergraduate (first, second, and third year) and 15.3 per cent postgraduate students. Afrikaans was indicated as the home language of 50.8 per cent of the respondents, while 68.3 per cent of the respondents indicated that English is there preferred language of tuition. In terms of race, 76.4 per cent of the students in the study identified themselves as "White". 


\section{Analysis}

Basic descriptive statistics were used to analyse the closed-ended Likert-scale responses associated to the general viewpoints regarding the economic feasibility of "free" higher education. Basic content analysis was utilised to scrutinise students' responses to the open questions. Quotes in the results section of this study signify representative responses - all chosen to inform the quantitative study results.

\section{RESULTS}

\section{Is South Africa able to provide "free" higher education to students?}

Students were asked to rate general statements about the economic feasibility of "free" higher education. They had to indicate whether they thought the South African government is able to implement "free" higher education and whether it is at all possible. The calculated mean and median are summarised in Table 1.

Table 1: Students' views on South Africa's ability to implement "free" higher education

\begin{tabular}{|l|c|c|}
\hline & Median & Mean \\
\hline A. "I think 'free' higher education is possible in South Africa" & 2 & 2.3 \\
\hline B. "I think the South African government is able to implement 'free' higher education" & 2 & 2.2 \\
\hline
\end{tabular}

The results depicted in Table 1 indicate that most of the EMS students do not seem to think that "free" higher education is economically feasible in South Africa, as only 23 per cent viewed it possible and 62 per cent viewed it as not possible. Students (66\%) also responded negatively to the statement that the South African government is able to implement "free" higher education. Only 21 per cent agreed that the South African government would be able to implement "free" higher education.

One open-ended question asked students whether South Africa is able to provide "free" higher education. They were also requested to provide a reason or reasons for their answers. Negative responses were received from 78.4 per cent $(n=820)$, while 21.6 per cent $(n=226)$ responded positively. A variety of reasons was offered, both positive and negative. Table 2 shows the main reasons why EMS students thought that South Africa would not be able to provide "free" higher education.

The majority of the respondents $(56.5 \% ; n=463)$ indicated that the South African economy is too weak and unstable to implement "free" higher education. This result relates to literature that notices and admits that the South African economy is under pressure (Cele and Nhlabathi 2017; Weekend Argus 2017). EMS students were of the opinion that part of the reason for the 
Table 2: Reasons provided by students as to why South Africa is not able to provide "free" higher education to its students

\begin{tabular}{|l|c|}
\hline Reasons & Percentage \\
\hline South African economy is too weak & 56.5 \\
\hline Corruption by the government & 39.9 \\
\hline Other government services are more important & 8.5 \\
\hline Misalignment of national budget by the government & 4.6 \\
\hline Decrease in quality of higher education & 2.7 \\
\hline Other reasons & 3.5 \\
\hline
\end{tabular}

Students were able to provide more than one reason. The total number of responses therefore adds up to more than $100 \%$.

weak economy is the fact that only a small percentage of the South African population currently pays tax. It would therefore place an unfair burden on the taxpayer to carry the full cost of "free" higher education. In addition, 39.9 per cent $(n=327)$ of respondents indicated that, due to current high levels of corruption and wasteful spending by the South African government, "free" higher education would not be possible. This view is supported by the study of Van der Merwe (2016) which also emphasised that the South African government should stop corruption. Furthermore, 8.5 per cent $(n=70)$ of the respondents specified other government services or sectors, especially primary education, as being more important than implementing "free" higher education. It is debatable which of the services funded by government is the most important, but truth is, for every percentage spent on one service, less is available for another service (Teferra 2016). The current inefficient spending and budget misalignment of spending with strategic goals were highlighted by 4.6 per cent $(n=38)$ of the respondents as reasons to why the South African government would not be able to implement "free" higher education. Van der Merwe (2016) also underscores the fact that the South African government should stop wasting money. In addition, 2.7 per cent $(n=21)$ of the respondents indicated that by making higher education "free", the quality of higher education would decrease. It was surprising to note that almost none of the students $(n=6)$ mentioned that universities would not be equipped for the increased numbers in students that would result from "free" higher education. In summary, the majority of respondents $(n=828)$ showed that South Africa would not be able to provide "free" higher education due to the weak economy and ineffective and corrupt governance. The following quotes represent typical responses:

"It is economically unstable and unable to bear these costs."

"Too small a percentage of the population pays tax to support this. The demand for funding is also far too high for the government to support at present, so I can't imagine free funding becoming a possibility." 
"The budget is generally in a deficit and we keep borrowing money to fund the country. The tax revenue gained should be utilised wisely, but government officials are corrupt and spend money lavishly like it's theirs to spend."

"South Africa can't even deliver free basic education that is of a decent standard. In offering free higher education, the standard of education will drop tremendously. They should be focusing their efforts on primary and secondary education."

Only 21.6 per cent $(n=226)$ of the respondents indicated that the South African government would be able to provide "free" higher education but only if certain conditions are met. The conditions provided for this view mirrored the responses of EMS students who thought that the South African government would not be able to provide "free" higher education; however, students who responded positively indicated that it would only be possible if those conditions highlighted were resolved or improved on. Table 3 shows the main responses from the respondents and displays the conditions that should be met to enable the South African government to provide "free" higher education.

Table 3: Conditions to be met to enable the South African government to provide "free" higher education

\begin{tabular}{|l|c|}
\hline Conditions & Percentage \\
\hline Less corruption in government & 61.1 \\
\hline Budget realignment and more effective spending by government & 23.9 \\
\hline Financial support only for students who need it & 2.2 \\
\hline Other reasons & 13.7 \\
\hline
\end{tabular}

Students were able to provide more than one response. The total number of responses therefore adds up to more than $100 \%$.

The majority of students that responded positively indicated that the South African government would only be in a position to implement "free" higher education if there were less corruption in government $(61.1 \%(\mathrm{n}=138))$, improved efficient spending, and budget realignment of funds to offer higher education by government $(23.9 \%(n=54))$. A shift in the alignment of the budget of South Africa is only possible if there is honest and open engagement regarding the country's resources (Vally et al. 2016). Some respondents $(2.2 \%(n=5))$ mentioned that only students who need financial support should be funded, while those who are able to pay should do so. A variety of other reasons and conditions $(n=31)$ were indicated by students. These ranged from the South African government being able to put into effect "free" higher education if the current standard of primary education was improved and if there were improved collaboration with the private sector in obtaining funding for higher education. The following sample of quotes represent the more typical positive responses:

"I feel the South African government is able to provide free higher education in addition to improved basic education. There are so many lost finances being used for corrupt or ineffective 
departments that can be utilised for education. Unrealistic salaries and an ineffective government cause wasted money that could be very well spent if it is just allocated and managed correctly." "Yes, but to an extent. I think the South African government would be able to if they only fund the tuition of students and only to a specific deserving group. They will not be able to fund for everyone whom want to study as that would cost too much."

"Yes. They are able to at some point in the future, but for that to happen, many other issues first need to be addressed such as the appalling standard of basic education and corruption that plagues government and hampering such options."

"The country may be able to afford free education in the future through proper planning and collaboration with the private sector and higher learning intuitions alumni who contribute to the institutions stream of funds."

\section{How may "free" higher education affect the South African economy?}

One of the research objectives of the study was to establish the views of EMS students on whether "free" higher education made any economic sense and how it might affect the South African economy. In the process it was also ascertained what students thought it would cost the South African government to implement "free" higher education.

EMS students were asked to rate a broad statement about whether they thought "free" higher education made economic sense. The calculated mean and median are summarised in Table 4.

Table 4: Student views on economic sense of "free" higher education in South Africa

\begin{tabular}{|l|c|c|}
\hline & Median & Mean \\
\hline C. "I think 'free' higher education makes economic sense in South Africa." & 2 & 2.2 \\
\hline
\end{tabular}

Only 20 per cent of EMS students agree that "free" higher education in South Africa makes economic sense, as illustrated in Table 4, while 63 per cent of the respondents indicated that it does not make economic sense.

Diverse responses became apparent from the open-ended question as to how, positively or negatively, "free" higher education may affect the South African economy. Most of the students responded negatively $(46.2 \%(n=475))$, while a few $(26.6 \%(n=273))$ responded positively. Some of the students $(19 \%(n=195))$ indicated that the economy would be influenced both positively and negatively by "free" higher education, while a small proportion of students $(8.2 \%(n=84))$ did not give any indication. A variety of responses was received as to how, positively or negatively, the South African economy may be affected. Table 5 presents a summary of respondent views on how the economy may be affected. 
Table 5: How "free" higher education may affect the South African economy

\begin{tabular}{|l|c|}
\hline Affect on the economy & Percentage \\
\hline Financial burden to a weak economy & 28.3 \\
\hline Further burden on the tax payer & 10.9 \\
\hline Other government services will be neglected & 8.6 \\
\hline Quality of higher education will decline & 5.4 \\
\hline Academically weak students will be funded & 5.4 \\
\hline No existing employment opportunities for new graduates & 3.3 \\
\hline Corruption in government will increase & 2.5 \\
\hline Universities will not be able to accommodate increased number of students & 1.3 \\
\hline More graduates for workforce in the long term & 34.4 \\
\hline
\end{tabular}

Students were able to provide more than one example (positive or negative). The total number of responses therefore adds up to more than $100 \%$.

Most of the respondents believed that the South African economy would be influenced negatively by "free" higher education. Following below are some examples of how students believed the economy might be negatively affected:

a) It would be placing an extra financial burden on an economy that is already weak $(n=286)$.

b) Currently there is a general shortage of funds for "free" higher education and implementing "free" higher education would put a further burden on the small percentage of the population that is currently paying tax $(n=110)$.

c) Other government services are more important and funds should be allocated to improve primary education, for example $(\mathrm{n}=87)$.

d) In the course of implementing "free" higher education, academically weak or nondeserving students will be funded $(\mathrm{n}=54)$. Also "free" higher education would lead to a decline in the standard of higher education in South Africa $(n=54)$.

e) Employment opportunities do not exist for new graduates $(\mathrm{n}=33)$.

f) As long as corruption in the government continues, "free" higher education would not be possible. However, should corruption be eliminated, it would be possible ( $\mathrm{n}=25)$.

These negative responses are also reflected in other studies. The main negative response, namely that "free" higher education would cause a financial burden to South Africa's weak economy, corresponds to the study by Wangenge-Ouma and Cloete (2008) which found that implementing "free" higher education would be too costly. Cloete (2016a) is of the opinion that increasing tax to fund higher education will subsidise the rich and increase the tax on the poor. Furthermore, the respondents' viewpoint that other services might be neglected concur with other studies (UNICEF 2016; Bloom et al. 2006; Gyimah-Brempong et al. 2006) which regard 
basic education and health services as more critical than higher education. However, even though the respondents indicated that there might not be employment opportunities for the new graduates, literature has shown that more graduates would be ideal in South Africa as economic growth relies on a good education (Hull 2015; Maistry 2014). Once again, students highlighted that government might mismanage additional funds allocated for "free" higher education, but the students also pointed out that if corruption is stopped, the economy could be positively effected (Van der Merwe 2016). The samples of quotes below reflect some of these views:

"Given the amount of cost that is linked to free education that the government has to provide, it would surely put our economy in bad state considering also the methods used to provide higher education for example tax increases, international loans, budget cuts that will lead to poor service delivery on its own etc."

"The first question would be where are we going to get the extra money? Further taxation and forcing employers to contribute money would have negative economic repercussions. Decreasing the standard of education would obviously be to the detriment of our economy."

"Money will be wasted, for students who pay for their education, is more likely to succeed. If you get something free, you are more inclined not to appreciate it as much, and many will only do that because it is free and don't worry to get good points as it will not affect your pocket."

"Should higher education be implemented funds that are currently implemented in more important issues such as health and housing would have to be decreased. The quality of higher education would also decrease as more of their budget would have to be allocated to providing lecturers and lecture halls for the students. There would also not be funds available to maintain the university facilities."

Many students also suggested that "free" higher education would positively influence the South African economy ( $n=347)$. They referred to the fact that in the short term the economy will be affected negatively, but that these challenges will in the future be surpassed by long-term economic benefits. Examples of such long-term benefits are a better skilled labour force, more graduates, reduced unemployment, and relieving of poverty. Some comments serve to illustrate:

"The economy will take a knock from the sudden high costs of funding free education, but the benefits of having more graduates, a higher degree of literacy and general knowledge, a better qualified population, will completely outweigh the disadvantages and initial "knock."

"It will strengthen the South African economy. More people would study and would make the economy more efficient, leading to new business ideas and creation, less unemployment, less crime, more exports and greater profits."

"Implementing free higher education will surely disadvantage the country economically, but as time progresses new leaders and better "products" will arise from the free education and maybe they will have a positive influence South Africa's economy."

In summary, the results shown in Table 6 seem to reveal that EMS students in general have a 
negative outlook on the effect that "free" higher education would have in the short term. Many students also recognised that if the government were able to eliminate corruption and wasteful spending, "free" higher education would lead to significant long-term advantages for the economy.

Students were also asked to estimate, according to their knowledge, the amount that would be required annually for implementing "free" higher education for 800000 undergraduate students in South Africa. The respondents were given certain ranges of Rand amounts to choose from. In Table 6, a summary of the answers by students to these categories provided, is presented.

Table 6: Estimated funds required for implementation of "free" higher education

\begin{tabular}{|l|c|}
\hline Amount & Percentage \\
\hline "Less than R1 million" & 0.5 \\
\hline "Between R1 million and R1 billion" & 7.1 \\
\hline "Between R1 billion and R10 billion" & 22.7 \\
\hline "Between R10 billion and R50 billion" & 40.1 \\
\hline "More than R50 million" & 29.6 \\
\hline
\end{tabular}

The results presented in Table 6 indicate that most students $(69.7 \%)$ believed that implementing "free" higher education would cost more than R10 billion per year, while almost a third (29.6\%) thought it would cost more than R50 billion per year. Close to 30 per cent thought it would cost less than R10 billion. These views mostly correlate with findings by Pienaar (2016), Badat (2016) and Cronje (2017) which indicated an estimated cost of anything between R20 billion and R60 billion per year for "free" higher education. Although some students anticipated an even higher cost, almost a third of the students surprisingly showed that they do not realise how high the cost could be and thus do not have a realistic expectation of the financial consequences of implementing "free" higher education.

\section{Is higher education more important than other government services?}

The final research goal of the study was to establish whether EMS students thought higher education is more important than other government services. Students who responded negatively were also asked to indicate which other government services were more important.

Results of this open-ended question showed that 69.6 per cent $(n=678)$ of students thought other government services are more important than higher education, while less than a third of the students $(30.4 \%(n=296))$ regarded higher education as the most important government 
service. These results stand in contrast to the findings of a study by Shrivastava and Shrisvastava (2014) which highlighted higher education as the most important service for a better economy in a developing country. Table 7 below presents a summary of the government services considered by commerce students as more important than higher education.

Table 7: Government services that are considered more important than higher education

\begin{tabular}{|l|c|}
\hline Government services & Percentage \\
\hline Health & 47.9 \\
\hline Basic education & 36.6 \\
\hline Public services (transport and water) & 28.0 \\
\hline Police, safety and security & 21.2 \\
\hline Housing and food & 14.8 \\
\hline Infrastructure & 11.7 \\
\hline Job creation & 2.1 \\
\hline Other services & 2.9 \\
\hline
\end{tabular}

Students were able to provide more than one other government service. The total number of responses therefore adds up to more than $100 \%$.

Almost 48 per cent $(n=325)$ of students indicated that allocating more funds to the health sector and providing "free" health care is of greater importance than higher education. Furthermore, improvement in the quality and accessibility of basic education was more important for 36.6 per cent $(n=248)$ of respondents. These two main services highlighted by the respondents are in line with other studies (UNICEF 2016; Hull 2015; Bloom et al. 2006) that also found health care and basic education to be more important than higher education. A significant number of EMS students $(49.2 \%(n=334))$ also thought that improving access to "free" housing, food, transport, and water is of greater strategic importance for the South African government than trying to implement "free" higher education. This result validates views previously expressed by students in the study that they do not think implementing "free" higher education would make economic sense.

\section{CONCLUSION}

The 2015 protests are a clear indication that there is unresolved issues in the higher education sector, including the shortage of government funding of higher education, the hike of tuition fees, student debt, and the most important factor as researched by this article, namely the resolution of "free" higher education (Badat 2016).

Higher education is a discipline of study and practice that represents the ambitions, aspirations and dreams of graduates with the prospect of jobs that are more fair, higher salaries and wages and higher living standards (Badat 2016). Granted that "free" higher education might be the leading way out of poverty and to increase economic growth in South Africa (Van der 
Merwe 2016), the implementation of this possibility unfortunately does not seem to make current economic sense. The report by the Fees Commission, led by Judge Jonathan Heher, has found that at this point, government lacks the capacity to provide "free" tertiary education to all students (Chabalala 2017). The real issue at hand is therefore not whether South Africa has the funding available for "free" higher education, but rather how the system can be made more accessible (Cloete 2016a). Moreover, according to Teferra (2016), not everyone is meant for higher education - one has to be sensible about one's abilities and expectations. Thus, considering accessibility, what the funding system for higher education in South Africa requires is fairness, and making higher education "free" will not contribute to the solution, as maintained by Hull (2015).

This study set out to determine the views of commerce students at one university in South Africa about the economic viability of "free" higher education. The results show that generally the respondents do not think that the South African government is capable to provide "free" higher education. The main reasons highlighted by respondents were that the South African economy is too weak and there is too much corruption and wasteful spending in government. Students were also of the opinion that the economy will largely be negatively affected by increasing the financial burden on an already weak South African economy and existing taxpayers. Most respondents were conscious of the enormous cost implication of funding "free" higher education, which might amount to billions of Rands. Furthermore, they regarded other government services like basic health and basic education more important than "free" higher education. In summary, the majority of the commerce students that participated in the study, did not think that "free" higher education would make economic sense.

The study has a few limitations which should be kept in mind in assessing the above results. The responses are only from EMS faculty students and students from other faculties at this particular university might have different views on "free" higher education. As other institutions may differ in terms of various factors, for example, type of student, policies, programmes offered, etc., the results of this study cannot be generalised beyond the scope of this particular institution. The context in which the student studies may significantly influence their views and perceptions. One further limitation to the study was that it primarily focused on students' personal views, which might however, not reflect reality.

The evidence from this study supports Cloete's (2016a) view that building a strong higher education system rather means that government funding should be spent more wisely and also affordable funding should be made available for the poor and lower middle class. In addition, Hull (2015) points out that higher education is an individual good and also a public good, and therefore should be funded by both parties, split 50:50 between government subsidies and 
students' fees.

A few suggestions are offered in the literature for increasing the accessibility of higher education. For example, a cost-sharing model is proposed by Wangenge-Ouma and Cloete (2008), which can make higher education more affordable for the underprivileged. Alternatively, a progressive graduate tax system is suggested where students pay back tuition fees through tax once they start earning a salary. This process disconnects the status of poor and rich families. However, this can only work if graduate rates are high, adequate employment is available, and a good tax collection system is in place (Cloete 2016a). Hull (2015) suggests a similar system, which offers loans to students that are repayable once the graduating student is earning above a certain threshold and can increase as the salary of the graduate increases. These and other alternative solutions will be discussed in a follow-up article.

The findings of the study suggest that "free" higher education would result in making unsustainable resource demands on government, which South Africa will not be fit to handle. Comparatively speaking, "free" higher education was thus far only realised by countries with strong economies, a firm and wide tax base and limited access to higher education. It is imperative that a solution be found in the long-term interest of the country, South Africa, and the higher education system thereof. Students need to accept that "free" higher education is not achievable in the short term (Pienaar 2016). Even leaders from other countries support the view that "free" higher education for all is just not financially feasible anymore (Memela 2015). Although the protests by students in South Africa might have engaged the country in a timely discussion on higher education and the government policy, it must be realised that "free" higher education is literally years away from becoming part of the country's policy (Memela 2015).

\section{NOTE}

1. The term "free" is indicated in inverted commas as no public service can be considered as "free". All education involves costs and thus there has to be adequate financial provision for such a service.

\section{REFERENCES}

Badat, S. 2016 Deciphering the meanings and explaining the South African higher education students protests of 2015-16. Pax Academica 1\&2: 71-106.

Bloom, D. E., D. Canning and K. Chan. 2006. Higher education and economic development in Africa. http://ent.arp.harvard.edu/AfricaHigherEducation/Reports/BloomAndCanning.pdf (Accessed 9 July 2018).

Bloom, D. E., D. Canning, K. Chan and D. L. Luca. 2014. Higher education and economic growth in Africa. International Journal of African Higher Education 1(1): 22-57.

Brooks, C. 2012. GDP: Value of goods and services. https://www.businessnewsdaily.com/3617-gdpdefinition.html (Accessed 5 July 2017). 
Bunce, L. 2017. The student-as-consumer approach in higher education and its effects on academic performance. Studies in Higher Education 42(11): 1958-1978.

Cele, S. and H. Nhlabathi. 2017. Fees won't fall. https://www.news24.com/SouthAfrica/ News/exclusive-fees-wont-fall-20171029-2 (Accessed 10 October 2017).

Chabalala, J. 2017. What Zuma does with fees commission report is entirely up to him - Heher. https://www.news24.com/SouthAfrica/News/what-zuma-does-with-fees-commission-report-isentirely-up-to-him-heher-20171113 (Accessed 14 November 2017).

Chowles, T. 2018. What the 2018 National budget means for the health sector. http://ehealthnews.co.za/ 2018-national-budget-means-health-sector/ (Accessed 6 July 2018).

Cloete, N. 2015. The flawed ideology of "free higher education". http://www.sun.ac.za/english/ Documents/CommOct2015/University\%20World\%20News\%20Cloete\%20article.pdf (Accessed 10 July 2017).

Cloete, N. 2016a. Free higher education? Why it's not possible in SA. Brilliant analysis! https://www.fin24.com/BizNews/free-higher-education-why-its-not-possible-in-sa-brilliantanalysis-20160928 (Accessed 9 July 2017).

Cloete, N. 2016b. The ideology of free higher education in South Africa. The poor, the rich and the missing middle? http://www.sun.ac.za/english/Documents/CommOct2015/Cloete\%202016\%20 The\%20poor\%20the\%20middle\%20and\%20the\%20rich.pdf (Accessed 10 July 2017).

Cronje, J. 2017. Fee-free university education "regressive" - Davis Tax Committee Report. https://www.fin24.com/Economy/fee-free-university-education-regressive-davis-tax-committeereport-20171113 (Accessed 14 November 2017).

Davids, N. 2016. \#FeesMustFall: History of South African student protests reflects inequality's grip. https://mg.co.za/article/2016-10-10-feesmustfall-history-of-south-african-student-protestsreflects-inequalitys-grip (Accessed 9 April 2017).

Gay, L. R. 1987. Educational research. Competencies for analysis and application. $3^{\text {rd }}$ Edition. Colombus: Merrill Publishing Company.

Gyimah-Brempong, K., O. Paddison and W. Mitiku. 2006. Higher Education and Economic Growth in Africa 42(3): 509-529.

Henning, E., W. van Rensburg and B. Smit. 2004. Finding your way in qualitative research. $1^{\text {st }}$ Edition. Pretoria: Van Schaik Publishers.

Hull, G. 2015. Free university education is not the route to social justice. https://mg.co.za/article/201510-28-free-university-education-is-not-the-route-to-social-justice (Accessed 9 July 2017).

Maistry, S. 2014. Education for economic growth: A Neoliberal fallacy in South Africa. Alternation 21(1): 57-75.

Memela, T. 2015. Investing in education a good strategy. https://www.iol.co.za/news/opinion/investingin-education-a-good-strategy-1948015 (Accessed 9 July 2017).

Nell, C. E. and M. C. Cant. 2014. Determining student perceptions regarding the most important service features and overall satisfaction with the service quality of a higher education institution. Management: Journal of Contemporary Management Issues 19(2): 63-87.

Pienaar, D. 2016. Higher education: Getting our priorities right. http://www.dnaeconomics.com/ pages/public_finance/?zDispID=NewsArtHigher_education_Getting_our_priorities_right (Accessed 9 July 2017).

Shrivastava, M. and S. Shrivastava. 2014. Political economy of higher education: Comparing South Africa to trends in the world. Higher Education 67: 809-822.

Teferra, D. 2016. Why free university in South Africa will be a massive mistake. https://mybroadband. co.za/news/technology/155076-why-free-university-in-south-africa-will-be-a-massivemistake.html (Accessed 9 July 2017).

UNICEF. 2016. Children and South Africa's health budget. https://www.unicef.org/esaro/ UNICEF_South_Africa_--_2016_--_Health_Budget_Brief.pdf (Accessed 9 July 2018). 
Vally, S., E. Motala, L. Naidoo, M. Hlatshwayo, R. Maharajh and Z. Marawu. 2016. Free education is possible if South Africa moves beyond smoke and mirrors. http://theconversation.com/freeeducation-is-possible-if-south-africa-moves-beyond-smoke-and-mirrors-65805 (Accessed 9 July 2017).

Van der Merwe, M. 2016. Insight: SA education - what comes next? https://www.dailymaverick. co.za/article/2016-09-06-insight-sa-education-what-comes-next/\#.W0IPPdIzZPY (Accessed 9 July 2017).

Venter, R. 2016. \#FeesMustFall and the SA Economy. http://studyres.com/doc/15030118/feesmustfalland-the-sa-economy (Accessed 12 July 2017).

Waghid, Y. 2002. Knowledge production and higher education transformation in South Africa: Towards reflexivity in university teaching, research and community service. Higher Education 43: 457488.

Wangenge-Ouma, G. and N. Cloete. 2008. Financing higher education in South Africa: Public funding, non-government revenue and tuition fees. South African Journal of Higher Education 22(4): 906919.

Weekend Argus. 2017. Free higher education would hit economy hard. https://www.iol.co.za/weekendargus/free-higher-education-would-hit-economy-hard-11968285 (Accessed 29 January 2018).

Wild, F. and A. Mbatha. 2015. Zuma lays bare SA's "serious struggle". https://www.iol.co.za/businessreport/economy/zuma-lays-bare-sas-serious-struggle-1937014 (Accessed 9 July 2018).

Wolpe, H. 1991. Education and social transformation: Problems and dilemmas. In Education in a future South Africa: Policy issues for transformation, ed. E. Unterhalter, H. Wolpe and T. Botha. London: Heinemann. 